Vochozka, M., Rowland, Z., Suler, P., \& Marousek, J. (2020). The Influence of the International Price of Oil on the Value of the EUR/USD Exchange Rate. Journal of Competitiveness, 12(2), 167-190. https:// doi.org/10.7441/joc.2020.02.10

\title{
THE INFLUENCE OF THE INTERNATIONAL PRICE OF OIL ON THE VALUE OF THE EUR/USD EXCHANGE RATE
}

\author{
- Marek Vochozka, Zuzana Rowland, Petr Suler, Josef Marousek.
}

\begin{abstract}
A great number of researchers argue that the development of large swathes of the global economy and competitiveness are influenced by fluctuations in international oil prices. The aim of this article is to determine to what extent those fluctuations in oil prices influence the value of the Euro relative to the value of USD. Data on the EUR/USD exchange rate were used for the analysis, with the time series that follow based on the price of Brent Crude. Statistica software (version 13) was used for the data processing. The research was based on a unified procedure with gradual changes in one parameter, namely in the time series (1, 5, 10 and 30 days), following which a regression analysis using neural networks was performed based on 10,000 networks that were generated for each experimental combination. As a result, eight calculations and eight different outcomes were obtained. From each experiment, the 5 artificial neural networks that showed the best results were retained. The outcomes suggest that the EUR/USD exchange rate is strongly dependent on the international price of oil. The impact of fluctuations in the price of oil on the EUR/USD exchange rate can therefore be accurately predicted. These results imply that it is also possible to predict the impact of such fluctuations on the performance of national economies. These predictions can be used to enhance competitiveness, including that of companies actively operating in international markets.
\end{abstract}

Keywords: oil price, exchange rate, artificial neural networks, time series, competitiveness JEL Classification: F31, E44, C45

Received: January, 2020

1st Revision: April, 2020

Accepted: May, 2020

\section{INTRODUCTION}

The article deals with two, at first glance distant, issues. This is a forecast of oil and the EUR/ USD exchange rate. The article tries to connect these two issues, to find a certain significant connection. Specifically, the aim of this article is to determine the effect of fluctuations in the international price of oil on the value of the Euro relative to the value of USD. In order to be able to appropriately determine the impact of the oil price on the development of the EUR/USD 
exchange rate, evaluate the current situation, and emphasize the benefits and importance of the contribution, we decided to begin by introducing an number of laws and other specific related factors.

The ability to predict the price of oil preoccupies the minds of academics, investors, government agencies and the like. Oil is considered to be a critical non-renewable source of energy which plays a significant role in the development of domestic and global economies (Goel \& Gupta, 2019). All sectors of an economy are affected by fluctuations in international oil prices (Qiang et al., 2019). Transport, housing, food, investment services and inflationary patterns are heavily influenced by the volatility of the price of oil. The global oil market is therefore a critically important driver of the global economy, but one that is also the prime focus of climate change policies (Liu et al., 2019). In addition, oil is at its core a negotiable monetary commodity and is therefore closely linked to the macroeconomic developments of recent years, including the instability of the stock market and the financial crisis (Oberholzer, 2017).

The movement of oil prices influences macroeconomic events and vice versa. Such events can dramatically affect cash flows in the financial industry as well as in other industries (Kaffash et al., 2020). In the last 30 years, several major events have either positively or negatively affected the international price of oil. In the 1970s, oil shocks triggered significant instability in the world economy, resulting in a period of economic stagflation. In the 1990s, the Gulf War along with the Asian crisis and Russian crisis resulted in a sharp decline in international oil prices. In contrast, the price of a barrel of oil increased between 2003 and 2008 due to the rise of China and India as economic powers. However, the financial crisis of 2008 subsequently saw a steep decline in oil prices (Ferreira et al., 2020).

Analysing the interactions between the price of oil and other assets has become a major topic of interest (Ferreira et al., 2020). Within this context, exchange rates can be seen as one of the most important indicators of how international oil price fluctuations are expressed in the real economy and financial markets (Goel \& Gupta, 2019). According to Aamir et al. (2018), the future price of oil strongly depends on past oil prices. However, this relationship has recently become far more uncertain and less predictable. Recent studies still confirm the fact that oil prices remain a dominant factor influencing real exchange rates, although differences across countries and time are acknowledged (Baghestani et al., 2019).

The theoretical background includes a literature review related to these relationships. In the methodological part, the research questions are presented, the data set described in detail, including statistical characteristics, and the calculation procedure (for both variants, including other sets of independent variables, and including the inclusion of time series delays) using artificial neural networks introduced. In the following section, the results of the calculations obtained for all variants are presented, followed by a discussion that seeks to resolve the research questions and compare the research results with other studies. The article concludes with a summary of the results and a statement on the benefits of the article and the limitations of the research. 


\section{THEORETICAL BACKGROUND}

Until recently, EU member states remained vulnerable to the effects of an economic crisis. The block's relatively poor economic performance resulted in volatile exchange rates, which reduced stability in the financial markets. Within this context, Mirdala \& Durčová (2016) conducted research into external price impulses and their effect on the EU member states' national market indices. The researchers applied the Value at Risk (VAR) methodology to examine the response of exchange rates to exogenous price shocks with the purpose of exploring the exchange rate dynamics that follow an unexpected oil price shock and its impact on national price indices. Their findings revealed differences in the abilities of countries with a fixed or flexible exchange rate to absorb such shocks.

Without a doubt, the price of oil has a major impact on the development of the global economy and the economies of individual countries. Horák (2019) suggests that economic development measured in terms of Gross National Product (GNP) is subsequently reflected in the price of the domestic currency. Benada (2014) goes further and states that oil constitutes an integral part of GNP using research focused on analysing the impact of oil price developments on the stock market in Prague, the Czech Republic. He claims that in some countries the ratio of oil to GNP is $4 \%$. The price of oil therefore constitutes a significant production cost with a huge knock-on effect on economic production. Nevertheless, it should be noted that the impact on the financial markets can also be caused by interest rates.

Zizkov et al. (2019) studied the interrelationship between oil and exchange rates in the major emerging markets of Eastern Europe, Asia, Arica and South America. By using phase arrows and phase differences, the examiners revealed a negative coherence between oil and exchange rates in oil importing countries during the financial crisis of 2008. In these countries, there was a negative coherence due to currency depreciation which was the result of the steep decline in the price of oil at the time. This aside, over the long term and during quiet periods phase differences showed a relatively stable in-phase dynamic.

Baek \& Kim (2019) examined the influence of fluctuations in the price of oil on exchange rates for selected sub-Saharan countries, providing strong evidence that such movements have an asymmetrical effect on actual exchange rates over the long term. Furthermore, Novotný (2012) claims that fluctuations in actual exchange rates are reflected more in the growth of the price of oil than in the fall thereof. Changes in oil prices have different impacts on the financial relationships that exist between global markets and economies.

In contrast, Breitenfeller \& Cuaresma (2008) explored the impact of changes in the EUR/USD exchange rate on oil prices. They indicate how the negative correlation they found between these two variables is caused by five possible channels. With regard to supply, this relates to the purchasing power of oil export profits, while with regard to demand it is related to local prices in the regions (which are not in USD), investments in markets with assets related to oil, monetary policy structures in oil exporting countries, as well as currency market performance. The authors demonstrate that the use of the EUR/USD exchange rate information significantly improves oil price forecasts. 
Another study conducted by Ji et al., (2020) examined the complex impact of various oil shocks on real exchange rates in net oil importing and exporting countries by integrating measures using a structural vector autoregressive model. The researchers discovered that shocks in oil supply cause a greater depreciative effect on the exchange rates of oil exporters than on oil importers. They concluded that all countries are highly sensitive to oil-specific demand shocks, and this vulnerability can lead to a significant increase in real exchange rates.

Horák et al. (2020) go even deeper into the heart of the matter. They suggest that oil (the price of oil in particular) heavily influences the development of the global economy and the economies of individual countries. Economic development as measured by GNP is subsequently reflected in the price of the domestic currency. The relationship between national currencies and the price of oil is therefore strongly evident. However, the central issue is whether and how this influence can be quantified and, if so, what significant relationship exists between the examined quantities. It is almost certain that this relationship will differ according to the level of development of the economy being analysed.

\section{RESEARCH OBJECTIVE, METHODOLOGY AND DATA}

The aim of this article is to determine the effect of fluctuations in the international price of oil on the value of the Euro relative to the value of USD. It is therefore necessary to first identify the relationship between oil and the Euro relative to the value of USD. If such a relationship is proven to exist, we can then measure its strength. On this basis, two research questions were formulated:

1. Is there a relationship between the price of Brent Crude and the value of the Euro relative to the value of USD?

2. Is it possible to measure the extent of the influence of the identified relationship?

The data for the analysis were taken from the Investing.com (2019a). For the analysis, data on the EUR/USD exchange rate was used. The price of Brent Crude expressed in USD/barrel constituted the second time series.

In light of the fact that prices in EUR will be expressed in relation to USD and the price of Brent Crude is also expressed in USD, it was necessary to eliminate the difference that could occur as a result of any fluctuations in the value of the USD. The data on the price of Brent Crude are available to the public on the Investing.com (2019b). The data for both variables covers the time interval starting on 1st September 2014 and ending on 30th August 2019. The price of Brent Crude represents the price of oil for approximately two-thirds of global production. It can therefore be argued that it reflects the price of oil worldwide (disregarding extreme values for specific economies burdened with various restrictions, e. g. international embargos).

Figure 1 graphically referents the basic statistical characteristics of development of the EUR/ USD exchange rate, including a histogram of the input data. 

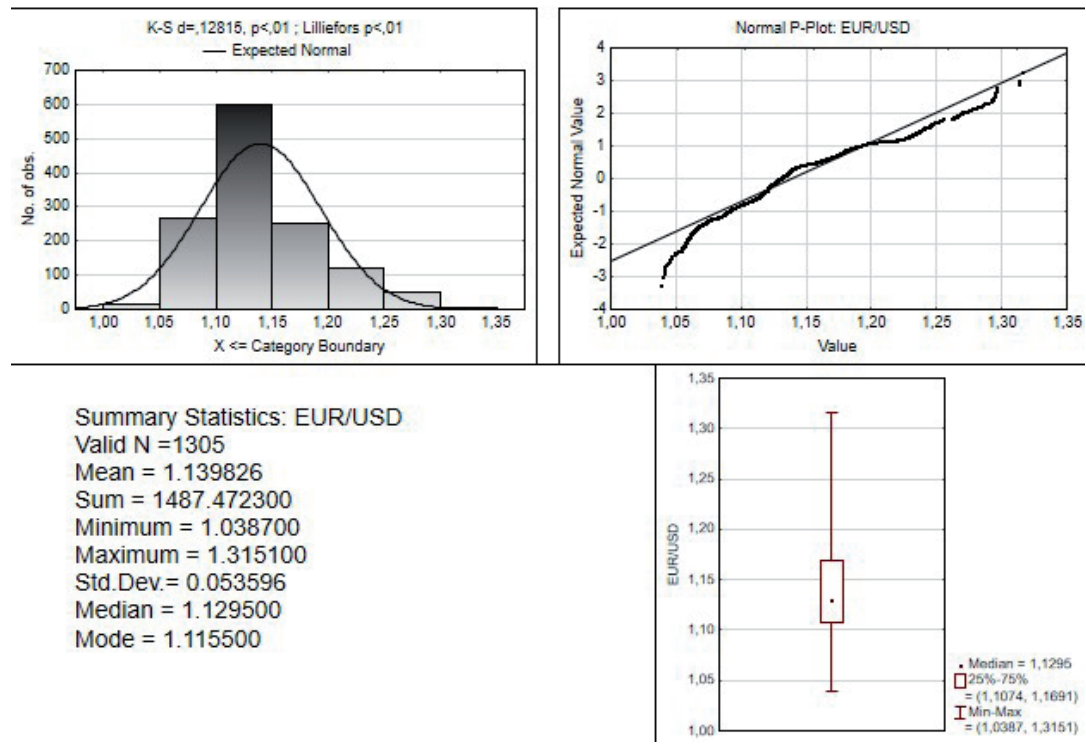

Fig. 1- Basic statistical characteristics of the EUR/USD exchange rate. Source: own research

Figure 2 presents the same characteristics for the second time series, i.e. prices for Brent Crude (in USD/barrel).
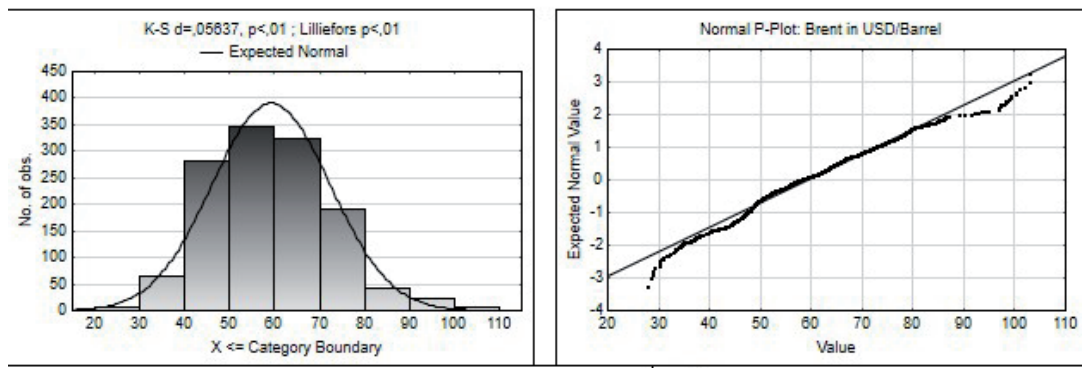

Summary Statistics: Brent in USD/Barre

Valid $\mathrm{N}=1290$

Mean $=50.227240$

Sum $=76403,140000$

Minimum $=27,880000$

Maximum $=102,790000$

Std. Dev $=13,178227$

Median $=57,540000$

Mode $=$ Multiple

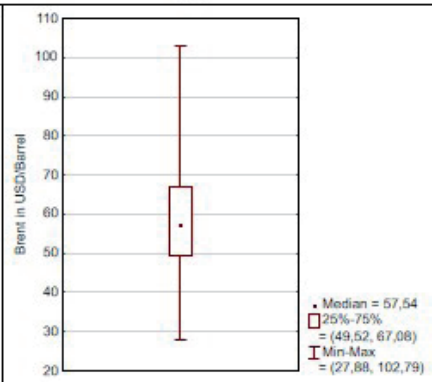

Fig. 2 - Basic statistical characteristics of the price of Brent Crude (in USD/barrel). Source: own research 
Interestingly, the histograms for both the EUR/USD exchange rate and the price of Brent Crude are very close to the normal distribution.

TIBCO's Statistica software (version 13) was used to process the data. In order to better understand the course of the examined time series, Figure 3 was compiled. The figure demonstrates the course of both time series in one combined diagram. The solid black line represents the course of the EUR/USD exchange rate and the dashed black line that of the price of Brent Crude. The $\mathrm{x}$-axis represents individual events in time. With respect to the application of the software, it is necessary to explain the reasoning behind the selected time interval, i.e. 1st September 2014 to 30th August 2019. The data for the research presented in this article were obtained at the start of the study. In other words, at the end of August 2019. For the study, the authors wanted to use a time series of exactly 5 years, which is the reason why the time interval starts on 1 st September 2014. Both time series therefore contain data for the monitored period. The Euro is always traded on working days, including Christmas (if the specific holiday falls on days other than a Saturday or Sunday) and Easter Monday. Brent Crude is only traded on working days. The y-axis on the left represents the EUR/USD exchange rate and on the right the price of Brent Crude (in $\mathrm{USD} / \mathrm{barrel})$. It is clear that there is a direct relationship between the development of both time series, although the difference is not constant, but volatile throughout.

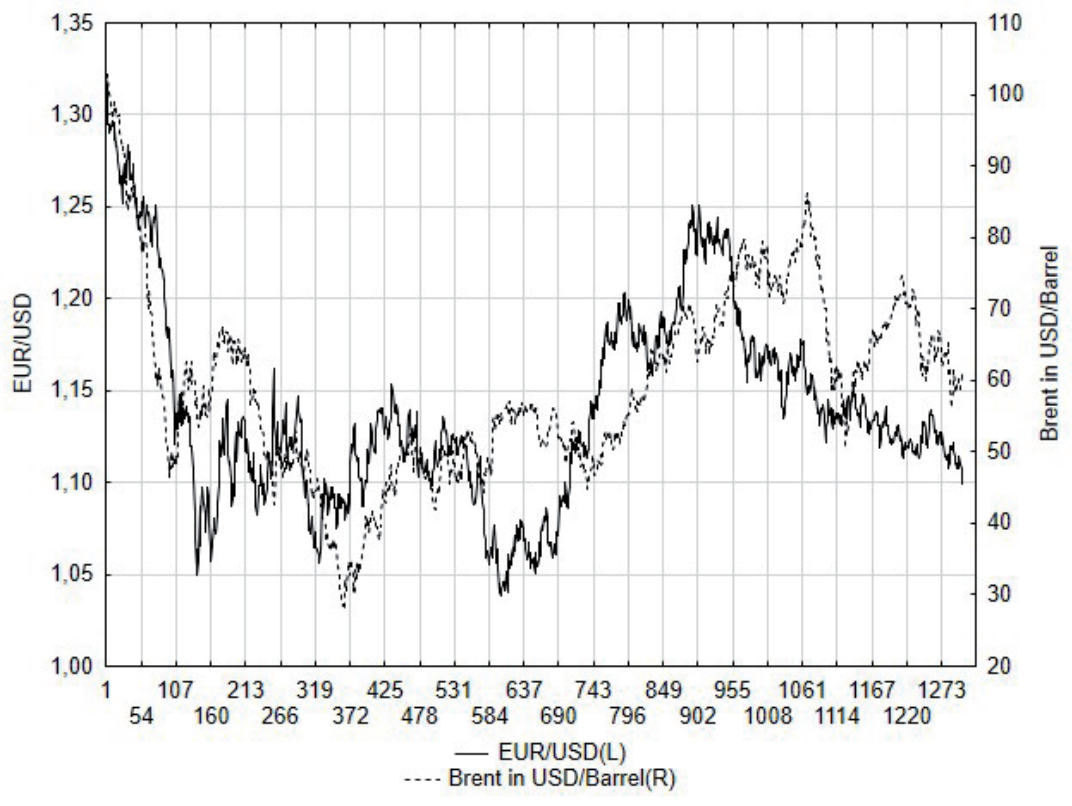

Fig. 3 - Development of the EUR/USD exchange rate and price of Brent Crude (in USD/barrel). Source: investing.com (2019a, 2019b); own research

At this point, it is necessary to consider that even though it appears there is mutual influence between the two, this does not have to be identifiable due the volatile differences during the time series. Unfortunately, because the time delay cannot be exactly expressed, this must be heuristically determined, i.e. based on the trend of both time series. This might seem misleading 
because the time series may have identical trends at two specific points, even though what comes before and after can be significantly different. In order to fulfil the goal of the research, it was therefore necessary to conduct an experiment.

If, as stated above, the time delay can only be determined in a heuristic way, the experiment had to therefore follow a unified procedure, whereby one parameter is gradually changed. In this case it is, a delay in the time series for the EUR/USD exchange rate. The expectations were as follows:

a) The change in the EUR/USD exchange rate will be delayed by 1 day after a change in the price of Brent Crude.

b) The change in the EUR/USD exchange rate will be delayed by 5 days after a change in the price of Brent Crude.

c) The change in the EUR/USD exchange rate will be delayed by 10 days after a change in the price of Brent Crude.

d) The change in the EUR/USD exchange rate will be delayed by 30 days after a change in the price of Brent Crude.

In light of the fact that the difference was not examined on one day, there was a risk that the actual time difference would be a provisional estimate rather than an exact calculation. The time difference can be constant, but differ from the estimate. The time difference may vary throughout the time series in separate time intervals. Despite this, it can be argued that the estimate is close to reality. Such a degree of accuracy was considered sufficient for the results presented in this article.

A regression analysis using neural structures from Statistica software was performed. Multilayer perceptron networks (MLP) and radial basis function neural networks (RBF) were generated, for which the EUR/USD exchange rate was the dependent variable. For the experiment, it was assumed there were two sets of independent variables:

1. Price of Brent Crude (continuous variable): in this case, only the relationship between the two variables was measured with a predefined time delay. This would enable us to answer the first research question, i.e. whether there is a relationship between the price of oil on the world market and the value of the Euro relative to the value of USD.

2. Price of Brent Crude and at the same time, date, day of the week, day of the month, month and year (continuous variables): in this case, by examining the relationship between the variables and measuring, if necessary, the significance of the relationship, it would be possible to answer both research questions. By default, only the price of Brent Crude and the date were used for this task. However, Horák et al. (2020) showed significantly better results when taking into account other time parameters than just the date in their calculations. The day of the week helps to reveal differences in the development of the time series within one week, the day of the month in one month, the month within a year and the year throughout the time series.

The time series was divided into three data sets - training, testing and validation data sets. The first group contained $70 \%$ of the input data. The training data set was used to generate the neural structures. The remaining data sets always stored $15 \%$ of the input data. The reliability of the identified neural structures was assessed for both groups. In total, 10,000 neural networks for 
each time difference were generated. As a result, four calculations for four different outputs were carried out. The five artificial neural networks with the best results were retained. The least squares method was then applied. Unless there was an improvement, i.e. the value of the total least squares decreased, the network generation was discontinued. Only those neural structures were retained for which the total of the residual squares in relation to the actual development of the EUR/USD exchange rate was the lowest possible (ideally zero). The hidden MLP layer contained 3-11 neurons. In the case of the radial basis function, the hidden layer contained no less than 21 neurons, but not more than 31 neurons. For the multilayer perceptron network, linear, logistic, atanh, exponential and sinus distribution functions were involved in the hidden and output layers. In all other cases, the default settings (according to ANS tool - Automated Neural Structures) were left as they are. If there was the need, the values of individual neurons were iterated using the VNS tool (Own Neural Networks). However, it should be noted that using this tool to improve ANS is an accidental process rather than an exact method with an in-advance estimated result.

The results of the retained neural networks for both groups were subsequently compared and a sensitivity analysis carried out. The performance of the neural networks provided an answer to the first research question, i.e. the relationship between the EUR/USD exchange rate and the price of Brent Crude. The sensitivity analysis provided the answer to the second research question, i.e. the extent of the influence of the price of Brent Crude on the EUR/USD exchange rate.

\section{RESULTS AND DISCUSSION}

The results of the calculations using the two sets of independent variables are presented below.

\subsection{Set 1: Dependence of the EUR/USD exchange rate on the price of Brent Crude}

Based on the established procedure, 10,000 neural networks were generated for each predefined time delay. The 5 best performing networks with a 1-day delay were retained and are presented in Table 1.

Tab. 1 - Retained neural networks with a 1-day time delay. Source: own research

\begin{tabular}{|c|c|c|c|c|c|c|c|c|c|c|c|}
\hline : & $\begin{array}{l}\text { Net- } \\
\text { work }\end{array}$ & $\begin{array}{l}\text { Training } \\
\text { perf. }\end{array}$ & $\begin{array}{l}\text { Test } \\
\text { perf. }\end{array}$ & $\begin{array}{l}\text { Valida- } \\
\text { tion } \\
\text { perf. }\end{array}$ & $\begin{array}{l}\text { Training } \\
\text { error }\end{array}$ & Test error & $\begin{array}{l}\text { Validation } \\
\text { error }\end{array}$ & $\begin{array}{l}\text { Training } \\
\text { algorithm }\end{array}$ & $\begin{array}{l}\text { Error } \\
\text { func- } \\
\text { tion }\end{array}$ & $\begin{array}{l}\text { Hidden } \\
\text { activa- } \\
\text { tion }\end{array}$ & $\begin{array}{l}\text { Output } \\
\text { activa- } \\
\text { tion }\end{array}$ \\
\hline 1 & $\begin{array}{l}\text { RBF } \\
1-29-1\end{array}$ & 0.697650 & 0.737654 & 0.669849 & 0.000707 & 0.000701 & 0.000809 & RBFT & sos & $\begin{array}{l}\text { Gaus- } \\
\text { sian }\end{array}$ & Identity \\
\hline 2 & $\begin{array}{l}\text { RBF } \\
1-26-1\end{array}$ & 0.696492 & 0.747918 & 0.669608 & 0.000710 & 0.000674 & 0.000810 & RBFT & sos & $\begin{array}{l}\text { Gaus- } \\
\text { sian }\end{array}$ & Identity \\
\hline 3 & $\begin{array}{l}\text { RBF } \\
1-25-1\end{array}$ & 0.682800 & 0.713358 & 0.667982 & 0.000737 & 0.000751 & 0.000820 & RBFT & SOS & $\begin{array}{l}\text { Gaus- } \\
\text { sian }\end{array}$ & Identity \\
\hline 4 & $\begin{array}{l}\text { RBF } \\
1-26-1\end{array}$ & 0.689711 & 0.750499 & 0.667209 & 0.000723 & 0.000667 & 0.000816 & RBFT & sos & $\begin{array}{l}\text { Gaus- } \\
\text { sian }\end{array}$ & Identity \\
\hline 5 & $\begin{array}{l}\text { RBF } \\
1-21-1\end{array}$ & 0.697221 & 0.750432 & 0.667780 & 0.000708 & 0.000668 & 0.000813 & RBFT & SOS & $\begin{array}{l}\text { Gaus- } \\
\text { sian }\end{array}$ & Identity \\
\hline
\end{tabular}


It is clear from the above that the best performing networks were RBF networks. According to the input data, there was only one variable in the input layer, namely the price of Brent Crude (continuous variable). This was represented by one neuron in the input layer. In the hidden layer, the neural networks contained from 21 to 29 neurons. In the output layer, there was logically only a single neuron and a single output variable, i.e. the EUR/USD exchange rate. The RBFT training algorithm was applied to all the retained networks. The neural structures used the Guassian curve to activate the hidden layer of neurons. An identical function was used to activate the outer layer of neurons (see Table 1 for details). All the retained neural structures used the sum of least squares as an error function. The performance is given by a correlation coefficient, which is relatively high across all the retained neural networks and data sets. For the training data set, these values are always above 0.68 , for test data set, always above 0.71 , and for the validation data set, always above 0.66 .

In the same way, the best networks for time delays of 5 days (Appendix 1), 10 days (Appendix 2) and 30 days (Appendix 3) were retained. The results are presented here verbally in order to save space.

The best performing neural networks for a time delay of 5 days were, once again, only RBF networks. In the hidden layer, the neural networks contained from 22 to 30 neurons. The RBFT training algorithm was applied to all the networks. The neural structures used the Guassian curve to activate the hidden layer of neurons. An identical function was used to activate the outer layer of neurons. All the retained neural networks used the sum of least squares as an error function. Even in this case, the values of the correlation coefficients were very high. For the training data set, these values were always above 0.69 , for the test data set, always above 0.64 , and for the validation data set, always above 0.71 .

Even in the case of the 10-day delay experiment, MLP networks did not prevail. The hidden layer of the retained RBF neural networks contained from 23 to 30 neurons. The output layer logically contained only a single neuron and a single output variable, i.e. the EUR/USD exchange rate. The RBFT training algorithm was applied to all the networks. The neural structures used the Guassian curve to activate the hidden layer of neurons. An identical function was used to activate the outer layer of neurons. All the retained neural structures used the sum of least squares as an error function. The correlation coefficients were, once again, very high, although they did not attain the same values as in the previous two time-delay experiments. Nevertheless, for the training data set, all the networks produced values above 0.69 , for the test data set, values above 0.65 , and for the validation data set, values always slightly above 0.64 .

Unlike the previous time-delay experiments, the best performing neural networks for the 30-day experiment were MLP networks. No RBF networks were retained. In the hidden layer, the neural networks contained from 5 to 8 neurons. The BFGS training algorithm (Quasi-Newton) was applied to all the networks, but always in a different form. The neural structures used hyperbolic tangent and logistic functions to activate the hidden layer of neurons. The logistic function was always used to activate the outer layer of neurons. All the retained neural structures used the sum of least squares as an error function. In this case, the performance was also given by a correla- 
tion coefficient, which ranged from more than 0.59 to more than 0.62 across the retained neural networks and data sets. Although these values are relatively high, they are not reflective of the results achieved in the other time-delay experiments.

The best performing neural networks are those where the correlation coefficient is ideally identical across the training, testing and validation data sets and the error is the lowest. All the retained neural networks showed a minimal error. However, the results for the one-day time delay experiment proved to be the highest performing across all the data sets.

\section{Results of neural networks with a one-day time delay:}

The performances of the individual data sets according to the retained neural networks are presented in Table 2 .

Tab. 2 - Correlation coefficients for the data sets. Source: own research

\begin{tabular}{|l|l|l|l|}
\hline Network & EUR/USD Train & EUR/USD Test & EUR/USD Validation \\
\hline $\begin{array}{l}1 . \mathrm{RBF} \\
1-29-1\end{array}$ & 0.697650 & 0.737654 & 0.669849 \\
\hline $\begin{array}{l}2 . \mathrm{RBF} \\
1-26-1\end{array}$ & 0.696492 & 0.747918 & 0.669608 \\
\hline $\begin{array}{l}3 . \mathrm{RBF} \\
1-25-1\end{array}$ & 0.682800 & 0.713358 & 0.667982 \\
\hline $\begin{array}{l}4 . \mathrm{RBF} \\
1-26-1\end{array}$ & 0.689711 & 0.750499 & 0.667209 \\
\hline $\begin{array}{l}5 . \mathrm{RBF} \\
1-21-1\end{array}$ & 0.697221 & 0.750432 & 0.667780 \\
\hline
\end{tabular}

The table shows that the performance of all the retained neural networks is approximately the same. The slight differences that exist between them do not have a significant effect on the performance of the individual networks. The value of the correlation coefficients for all data sets ranges from almost 0.67 to more than 0.75 . For the training data sets, these values range from more than 0.68 to almost 0.7 , for the test data set, from more than 0.71 to more than 0.75 , and for the validation data, almost 0.67 . In order to select the most suitable neural network, it was necessary to perform a more detailed analysis of the obtained results. Table 3 presents the basic statistical characteristics of the data sets for the retained neural networks. 
Tab. 3 - Statistical characteristics of the data sets according to the retained neural networks. Source: own research

\begin{tabular}{|c|c|c|c|c|c|}
\hline Statistics & 1.RBF 1-29-1 & 2.RBF $1-26-1$ & 3.RBF 1-25-1 & 4.RBF 1-26-1 & 5.RBF 1-21-1 \\
\hline $\begin{array}{l}\text { Minimum prediction } \\
\text { (Train) }\end{array}$ & 1.08308 & 1.08091 & 1.07325 & 1.06776 & 1.08639 \\
\hline $\begin{array}{l}\text { Maximum prediction } \\
\text { (Train) }\end{array}$ & 1.27331 & 1.28995 & 1.25879 & 1.28810 & 1.29143 \\
\hline Minimum prediction (Test) & 1.08446 & 1.08128 & 1.08147 & 1.08562 & 1.08781 \\
\hline $\begin{array}{l}\text { Maximum prediction } \\
\text { (Test) }\end{array}$ & 1.27323 & 1.28968 & 1.25854 & 1.28779 & 1.29118 \\
\hline $\begin{array}{l}\text { Minimum prediction } \\
\text { (Validation) }\end{array}$ & 1.08309 & 1.08197 & 1.07427 & 1.08007 & 1.08640 \\
\hline $\begin{array}{l}\text { Maximum prediction } \\
\text { (Validation) }\end{array}$ & 1.27274 & 1.28964 & 1.25787 & 1.28650 & 1.28984 \\
\hline Minimum residual (Train) & -0.09580 & -0.09079 & -0.09261 & -0.09232 & -0.08218 \\
\hline Maximum residual (Train) & 0.11265 & 0.11782 & 0.11816 & 0.11591 & 0.11129 \\
\hline Minimum residual (Test) & -0.09045 & -0.08333 & -0.09618 & -0.08533 & -0.07340 \\
\hline Maximum residual (Test) & 0.11695 & 0.11280 & 0.10941 & 0.10446 & 0.11350 \\
\hline $\begin{array}{l}\text { Minimum residual (Valida- } \\
\text { tion) }\end{array}$ & -0.08612 & -0.08196 & -0.08010 & -0.08430 & -0.07596 \\
\hline $\begin{array}{l}\text { Maximum residual (Valida- } \\
\text { tion) }\end{array}$ & 0.10688 & 0.11216 & 0.11503 & 0.11019 & 0.10737 \\
\hline $\begin{array}{l}\text { Minimum standard re- } \\
\text { sidual (Train) }\end{array}$ & -3.60180 & -3.40834 & -3.41094 & -3.43445 & -3.08823 \\
\hline $\begin{array}{l}\text { Maximum standard re- } \\
\text { sidual (Train) }\end{array}$ & 4.23557 & 4.42290 & 4.35213 & 4.31222 & 4.18175 \\
\hline $\begin{array}{l}\text { Minimum standard re- } \\
\text { sidual (Test) }\end{array}$ & -3.41666 & -3.21003 & -3.51062 & -3.30465 & -2.84011 \\
\hline $\begin{array}{l}\text { Maximum standard re- } \\
\text { sidual (Test) }\end{array}$ & 4.41739 & 4.34515 & 3.99340 & 4.04545 & 4.39181 \\
\hline $\begin{array}{l}\text { Minimum standard re- } \\
\text { sidual (Validation) }\end{array}$ & -3.02768 & -2.87917 & -2.79693 & -2.95083 & -2.66388 \\
\hline $\begin{array}{l}\text { Maximum standard re- } \\
\text { sidual (Validation) }\end{array}$ & 3.75759 & 3.94002 & 4.01670 & 3.85702 & 3.76523 \\
\hline
\end{tabular}

Ideally, the individual statistics for the neural network are identical across all the data sets (minima, maxima, residues, etc.). However, in the case of balanced values, the differences are minimal. In principle, minimal differences are also observed in the characteristics of residues. Nevertheless, we are not able to unambiguously determine which of the preserved neural networks shows the most suitable results.

Figure 4 is a line graph that not only shows the actual development of the EUR/USD exchange rate as a function of the price of Brent Crude, but also time regression curves according to the retained time series. 
It is evident from the graph that all the retained neurons can predict the main basic direction of the EUR/USD exchange rate and can, in most cases, reliably predict local minima and maxima.

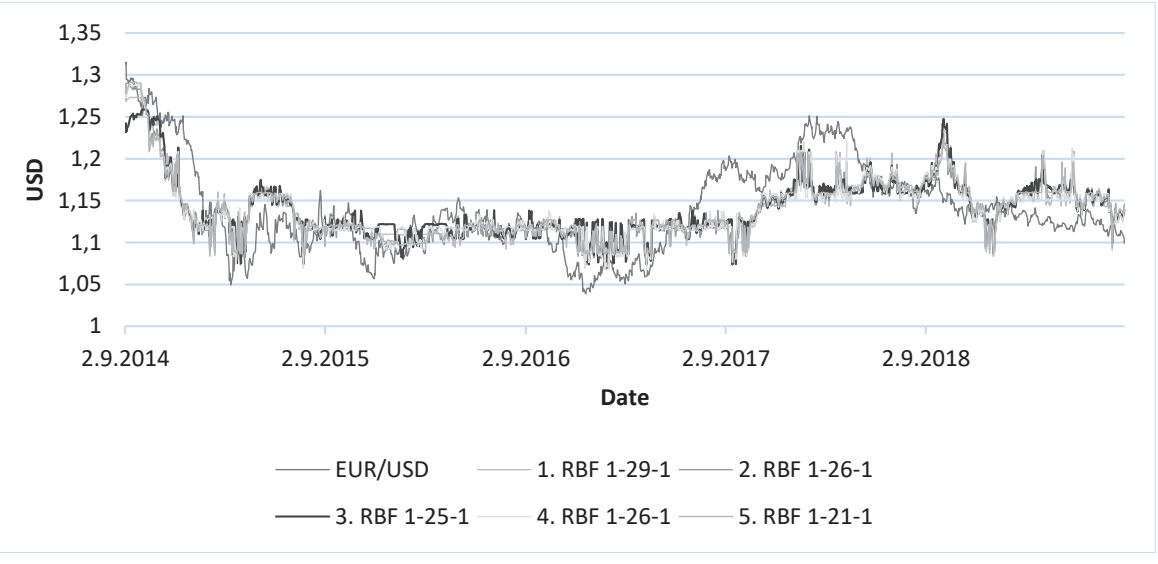

Fig. 4 - Development of the EUR/USD exchange rate as a function of the price of Brent Crude during the observed period. Source: own research

In summary, the 2.RBF 1-26-1 neural network shows the best results, albeit only slightly. The network always produces a balanced performance across all the data sets, which is also very high. The second most successful network is one with a neural structure with the same time delay, namely 5.RBF 1-21-1. Compared to the most successful network, its performance fluctuates more across the data sets.

\subsection{Set 2: Dependence of the EUR/USD exchange rate on the price of Brent Crude over time}

Based on the predetermined methodology, four sets of results were generated. The independent variables are the price of Brent Crude (in USD/barrel), date, day of the week, day of the month, and year. In each case, only 5 of the 10,000 generated artificial neural networks were retained. In Table 4, the retained neural networks with a 1-day time delay are presented.

Tab. 4 - Retained neural networks with a 1-day time delay. Source: own research

\begin{tabular}{|c|c|c|c|c|c|c|c|c|c|c|c|}
\hline 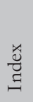 & Network & $\begin{array}{l}\text { Training } \\
\text { perf }\end{array}$ & Test perf. & $\begin{array}{l}\text { Valida- } \\
\text { tion perf. }\end{array}$ & $\begin{array}{l}\text { Training } \\
\text { error }\end{array}$ & $\begin{array}{l}\text { Test } \\
\text { error }\end{array}$ & $\begin{array}{l}\text { Valida- } \\
\text { tion } \\
\text { error }\end{array}$ & $\begin{array}{l}\text { Training } \\
\text { algorithm }\end{array}$ & $\begin{array}{l}\text { Error } \\
\text { func- } \\
\text { tion }\end{array}$ & $\begin{array}{l}\text { Hidden } \\
\text { activa- } \\
\text { tion }\end{array}$ & $\begin{array}{l}\text { Output } \\
\text { activation }\end{array}$ \\
\hline 1 & $\begin{array}{l}\text { MLP } \\
6-10-1\end{array}$ & 0.983874 & 0.979428 & 0.985504 & 0.000044 & 0.000063 & 0.000043 & BFGS 311 & SOS & Tanh & Identity \\
\hline 2 & $\begin{array}{l}\text { MLP } \\
6-11-1\end{array}$ & 0.984621 & 0.983114 & 0.985199 & 0.000042 & 0.000052 & 0.000044 & BFGS 398 & SOS & Tanh & $\begin{array}{l}\text { Exponen- } \\
\text { tial }\end{array}$ \\
\hline 3 & $\begin{array}{l}\text { MLP } \\
6-11-1\end{array}$ & 0.983383 & 0.979673 & 0.985493 & 0.000045 & 0.000062 & 0.000043 & BFGS 304 & SOS & Tanh & Identity \\
\hline
\end{tabular}




\begin{tabular}{|c|l|l|l|l|l|l|l|l|l|l|l|}
\hline 4 & $\begin{array}{l}\text { MLP } \\
6-11-1\end{array}$ & 0.985335 & 0.983905 & 0.985499 & 0.000040 & 0.000050 & 0.000043 & BFGS 354 & SOS & Tanh & Sine \\
\hline 5 & $\begin{array}{l}\text { MLP } \\
6-11-1\end{array}$ & 0.984551 & 0.980770 & 0.986588 & 0.000042 & 0.000058 & 0.000040 & BFGS 330 & SOS & Tanh & Logistic \\
\hline
\end{tabular}

The best characteristics were shown by MLP networks. The input layer contained six continuous variables. The neural networks in the hidden layer contained 10 and 11 neurons. The output layer contained one neuron and one output variable, i.e. the EUR/USD exchange rate. The Quasi-Newton training algorithm (a different form of BFGS for each network) was applied to all the networks. For the activation of the hidden layer of neurons, the hyperbolic tangent function was used, whilst for the activation of the output layer, the exponential, hyperbolic tangent, identity, sine and logistic functions were used (for more details, see Table 1). All the retained neural networks used the sum of least squares method as an error function. The performance of the retained networks is very high. For the training data set, the correlation coefficients for the retained neural networks was always higher than 0.98 , for the testing data set, close to 0.98 and higher, and for the validation data set, above 0.98 , which is a very positive result.

As with Set 1, the best performing neural networks with a 5-day (Appendix 4), 10-day (Appendix 5) and 30-day (Appendix 6) delay were also identified and presented in the same manner. For the 5-day delay experiment, the MLP networks also showed the best characteristics. The hidden layer contained between 9 and 11 neurons. The output layer contained only one neuron and one output variable, i.e. the EUR/USD exchange rate. The Quasi-Newton training algorithm (a different form for each network) was applied to all the networks. For the activation of the hidden layer of neurons, the hyperbolic tangent and logistic functions were used, whilst for the activation of the output layer, the hyperbolic tangent, sinus and identity functions were used. All the retained neural networks used the sum of least squares method as an error function. For the 5 -day delay, the performance across all the data sets was also very high, with the values of almost 0.98 and higher.

In the case of the 10-day time delay experiment, the best preforming neural networks were the MLP networks. The input layer contained six continuous variables. The hidden layer contained between 8 and 11 neurons. The output layer contained only one neuron and one output variable, i.e. the EUR/USD exchange rate. The Quasi-Newton training algorithm (a different form of BFGS for each network) was applied to all the networks. For the activation of the hidden layer, the hyperbolic tangent and logistic functions were used, whilst for the activation of the output layer, the logistic, sine, identity and hyperbolic tangent functions were used (for more details, see Table 3). All the retained neural networks used the sum of least squares method as an error function. Even in this case, the values of the correlation coefficients for all the retained neural networks across all the data sets ranged from more than 0.97 to more than 0.98 .

In the case of the 30-day time delay experiment, the best performing neural networks were, once again, the MLP networks. The input layer contained two variables. The hidden layer always contained 11 neurons. The BFGS training algorithm (a different form for each network) was applied to all the networks. For the activation of the hidden layer, the hyperbolic tangent and logistic functions were used, whilst for the activation of the output layer, the sine, identity, exponential and hyperbolic tangent functions were used. All the retained neural networks used the sum of 
least squares method as an error function. In this case, the values of the correlation coefficients for all the retained neural networks across all the data sets all ranged from more than 0.97 to more than 0.98 .

With correlation coefficients of almost 0.98 and higher, the performance of all the retained neural networks indicate an almost direct dependence. Time, as an integral part of the calculation, plays a significant role. It can therefore be deduced that the development of the EUR/USD exchange rate can be accurately estimated and predicted over time. The question remains, however, what the influence of the price of Brent Crude is on the EUR/USD exchange rate. When comparing the results by time delay, it can be concluded that the retained neural networks that show the best performance characteristics were those with the 1-day delay. The following section therefore focuses on these retained neural networks and their data sets.

\section{Results of neural networks with a one day time delay:}

The performance of the retained neural networks with a 1-day time delay across the data sets, as indicated by the values of the correlation coefficients, are presented in Table 5 .

Tab. 5 - Correlation coefficients for the data sets. Source: own research

\begin{tabular}{|l|l|l|l|}
\hline & EUR/USD - Train & EUR/USD - Test & EUR/USD - Validation \\
\hline 1.MLP 6-10-1 & 0.983874 & 0.979428 & 0.985504 \\
\hline 2.MLP 6-11-1 & 0.984621 & 0.983114 & 0.985199 \\
\hline 3.MLP 6-11-1 & 0.983383 & 0.979673 & 0.985493 \\
\hline 4.MLP 6-11-1 & 0.985335 & 0.983905 & 0.985499 \\
\hline 5.MLP 6-11-1 & 0.984551 & 0.980770 & 0.986588 \\
\hline
\end{tabular}

The results show that the differences in performance of the retained neural networks is minimal. With correlation coefficient values across all the data sets of almost 0.98 and higher, this indicates that all the retained neural networks are applicable. However, the performance of the second and fourth neural networks (4.MLP 6-11-1 and 2.MLP 6-11-1) appears to be slightly higher. In order to choose the most suitable neural network, a more detailed analysis of the results needed to be carried out. Table 6 presents the basic statistical characteristics of the data sets for the retained neural networks.

Tab. 6 - Statistical characteristics of the data sets according to the retained neural networks.

Source: own research

\begin{tabular}{|l|l|l|l|l|l|}
\hline Statistics & 1.MLP 6-10-1 & 2.MLP 6-11-1 & 3.MLP 6-11-1 & 4.MLP 6-11-1 & 5.MLP 6-11-1 \\
\hline $\begin{array}{l}\text { Minimum prediction } \\
\text { (Train) }\end{array}$ & 1.03899 & 1.04192 & 1.04739 & 1.04144 & 1.04560 \\
\hline $\begin{array}{l}\text { Maximum prediction } \\
\text { (Train) }\end{array}$ & 1.29251 & 1.30499 & 1.28577 & 1.29277 & 1.28866 \\
\hline $\begin{array}{l}\text { Minimum prediction } \\
\text { (Test) }\end{array}$ & 1.04951 & 1.04849 & 1.05016 & 1.04703 & 1.04784 \\
\hline
\end{tabular}




\begin{tabular}{|l|l|l|l|l|l|}
\hline $\begin{array}{l}\text { Maximum prediction } \\
\text { (Test) }\end{array}$ & 1.29246 & 1.32661 & 1.28637 & 1.29418 & 1.28946 \\
\hline $\begin{array}{l}\text { Minimum prediction } \\
\text { (Validation) }\end{array}$ & 1.04103 & 1.04212 & 1.04659 & 1.04385 & 1.04581 \\
\hline $\begin{array}{l}\text { Maximum prediction } \\
\text { (Validation) }\end{array}$ & 1.28683 & 1.30198 & 1.28501 & 1.29056 & 1.28715 \\
\hline $\begin{array}{l}\text { Minimum residual } \\
\text { (Train) }\end{array}$ & -0.03937 & -0.03291 & -0.03891 & -0.03007 & -0.03565 \\
\hline $\begin{array}{l}\text { Maximum residual } \\
\text { (Train) }\end{array}$ & 0.03509 & 0.03228 & 0.04172 & 0.03983 & 0.03769 \\
\hline $\begin{array}{l}\text { Minimum residual } \\
\text { (Test) }\end{array}$ & -0.04208 & -0.03080 & -0.04361 & -0.03495 & -0.03945 \\
\hline $\begin{array}{l}\text { Maximum residual } \\
\text { (Test) }\end{array}$ & 0.03491 & 0.03380 & 0.03032 & 0.02316 & 0.02564 \\
\hline $\begin{array}{l}\text { Minimum residual } \\
\text { (Validation) }\end{array}$ & -0.03009 & -0.02313 & -0.03068 & -0.02321 & -0.02727 \\
\hline $\begin{array}{l}\text { Maximum residual } \\
\text { (Validation) }\end{array}$ & 0.02748 & 0.02861 & 0.02585 & 0.02429 & 0.02639 \\
\hline $\begin{array}{l}\text { Minimum standard } \\
\text { residual (Train) }\end{array}$ & -5.92839 & -5.07401 & -5.77354 & -4.74669 & -5.48487 \\
\hline $\begin{array}{l}\text { Maximum standard } \\
\text { residual (Train) }\end{array}$ & 5.28385 & 4.97701 & 6.19028 & 6.28775 & 5.79784 \\
\hline $\begin{array}{l}\text { Minimum standard } \\
\text { residual (Test) }\end{array}$ & -5.32000 & -4.27671 & -5.55965 & -4.96609 & -5.17063 \\
\hline $\begin{array}{l}\text { Maximum standard } \\
\text { residual (Test) }\end{array}$ & 4.41418 & 4.69324 & 3.86638 & 3.29160 & 3.36157 \\
\hline $\begin{array}{l}\text { Minimum standard } \\
\text { residual (Validation) }\end{array}$ & -4.57498 & -3.48346 & -4.67136 & -3.54379 & -4.30811 \\
\hline $\begin{array}{l}\text { Maximum standard } \\
\text { residual (Validation) }\end{array}$ & 4.17826 & 4.30846 & 3.93619 & 3.70874 & 4.16972 \\
\hline
\end{tabular}

Under ideal circumstances, the individual statistics for the neural networks should horizontally be the same across all the data sets (minimum, maximum, residuals, etc.). In this case, the differences are minimal not only between the individual data sets for one network, but also between the individual networks. In terms of the residual values, the most successful appears to be the 4.MLP 6-11-1 network.

An interesting comparison of the performance of the retained neural networks is presented in Figures 5 and 6 . The $\mathrm{x}$-axis of the scatter plots shows the actual/predicted price of Brent Crude (in USD/barrel) and the $y$-axis the actual/predicted EUR/USD exchange rate. 


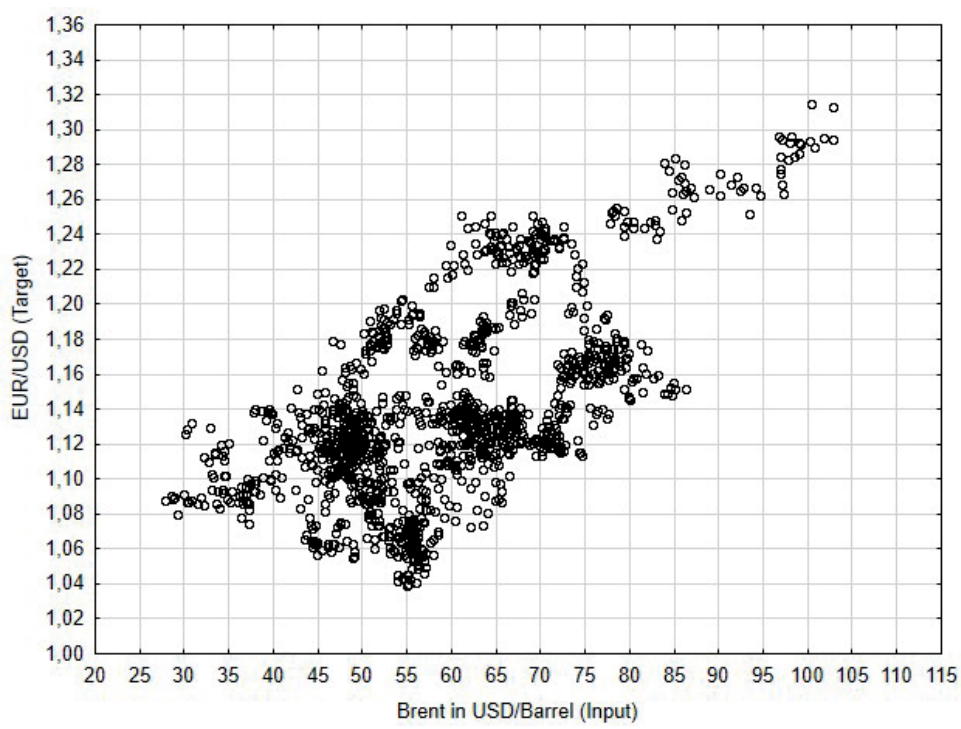

Fig. 5 - Actual price of Brent Crude and the EUR/USD exchange rate. Source: investing.com (2019a, 2019b); own research

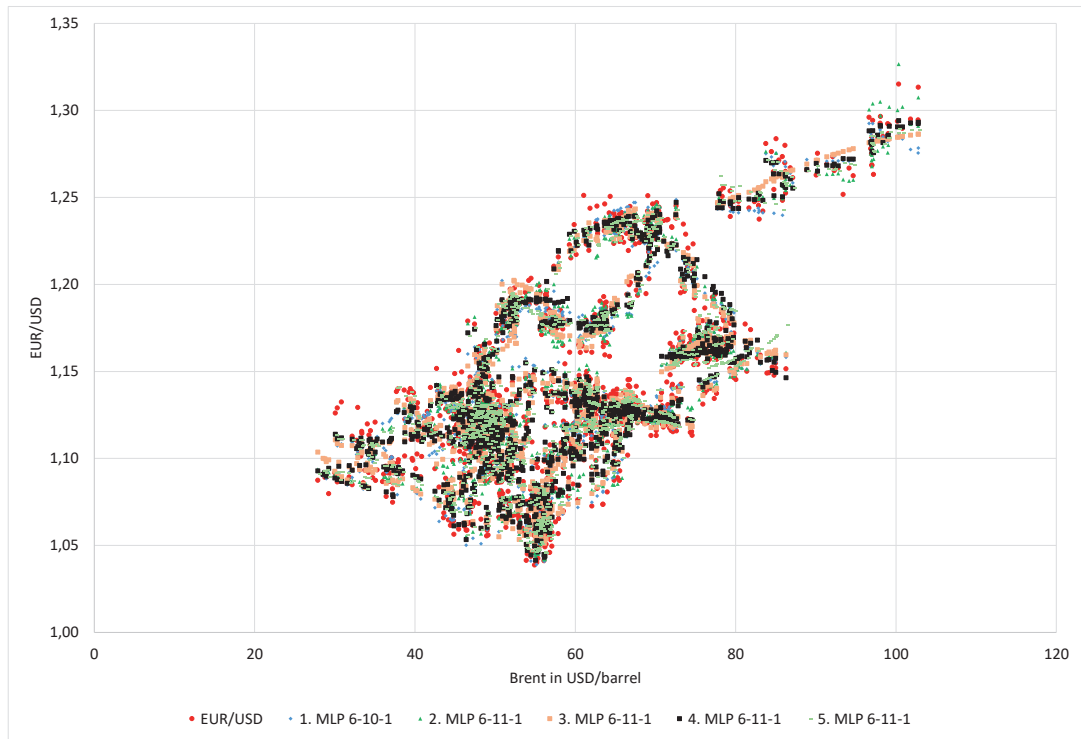

Fig. 6 - Predicted price of Brent Crude and the EUR/USD exchange rate. Source: own research

It is clear from the figures that the actual and predicted values almost overlap, which confirms the accuracy of the performance of the retained neural networks. However, it is not possible to deduce which of them generates the most precise result. 
It is also not clear whether one or some of the retained neural networks show significantly better characteristics than the others. However, it is possible to notice slight differences. It can therefore be concluded that, even though all the retained neural networks are applicable (Figure 7), the most successful one in this part of the experiment is the 4.MLP 6-11-1 network, followed by the 2.MLP 6-11-1 network.

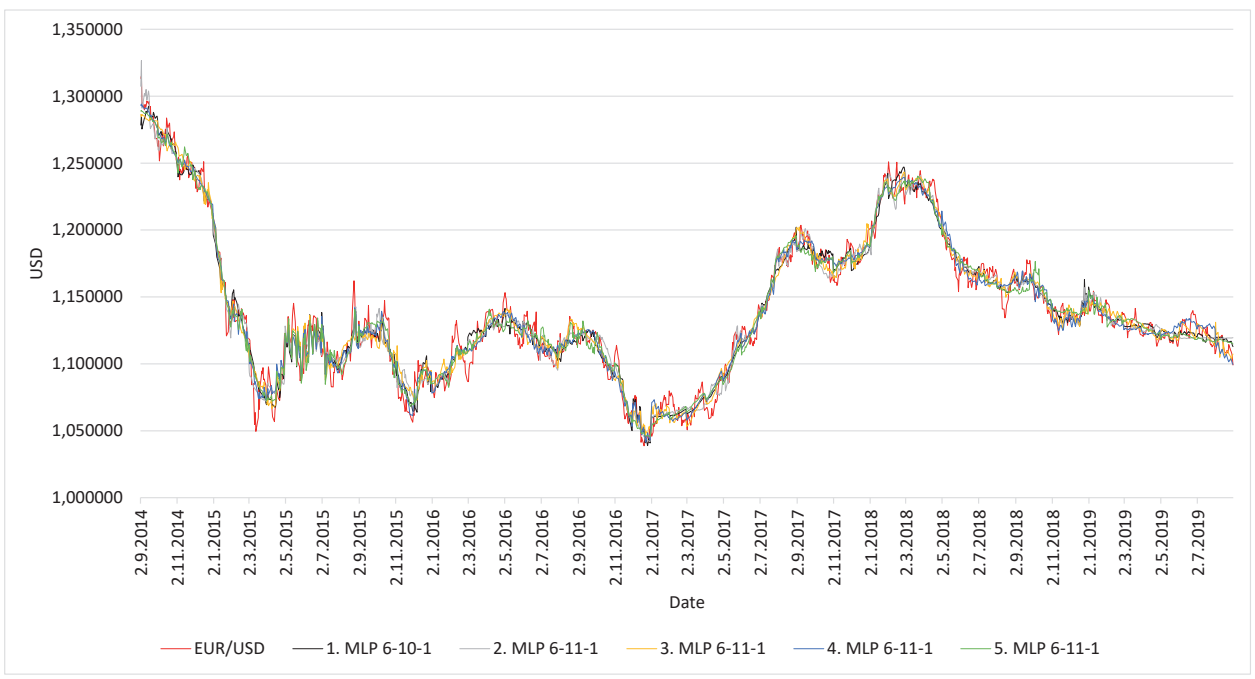

Fig. 7 - Development of the EUR/USD exchange rate in relation to the price of Brent Crude during the monitored period. Source: own research

The figure shows the capability of the retained neural networks to capture both global and local extremes.

\subsection{Discussion: evaluation, research questions}

Based on the results obtained, it is evident that the development of the EUR/USD exchange rate is dependent on the price of Brent Crude and that it is possible to determine the time delay at which this happens. The best results were obtained with a 1-day time delay of the EUR/USD exchange rate time series. The delay was identified through the calculation of the mutual dependence of both time series and the inclusion of another variable - time (in the form of a date, day in the week, day in the month, month, and year). By including time as an independent variable, it was possible to examine time series that were only partially influenced by the development of the price of Brent Crude. In order to be able to specify the influence of the price of Brent Crude on the value of the euro relative to the value of USD, a sensitivity analysis to time and the price of Brent Crude was performed on the predicted values. The results are presented in Table 7. 
Tab. 7 - Sensitivity analysis of the EUR/USD exchange rate to the time and price of Brent Crude. Source: own research

\begin{tabular}{|l|l|l|l|l|l|l|}
\hline Network & Year & $\begin{array}{l}\text { Date } \\
\text { EUR/USD }\end{array}$ & Month & $\begin{array}{l}\text { Brent in } \\
\text { USD/Barrel }\end{array}$ & $\begin{array}{l}\text { Day in } \\
\text { Month }\end{array}$ & $\begin{array}{l}\text { Day in } \\
\text { Week }\end{array}$ \\
\hline $\begin{array}{l}\text { 1.MLP } \\
\text { 6-10-1 }\end{array}$ & $2.425313 \mathrm{E}+03$ & 2533.319 & 148.6802 & 9.4532 & 2.363766 & 1.004235 \\
\hline $\begin{array}{l}\text { 2.MLP } \\
\text { 6-11-1 }\end{array}$ & $4.809552 \mathrm{E}+12$ & 65.635 & 44.0370 & 148.0949 & 1.950455 & 1.004115 \\
\hline $\begin{array}{l}\text { 3.MLP } \\
\text { 6-11-1 }\end{array}$ & $7.754709 \mathrm{E}+02$ & 809.886 & 63.6075 & 19.6293 & 1.699942 & 1.000821 \\
\hline $\begin{array}{l}\text { 4.MLP } \\
\text { 6-11-1 }\end{array}$ & $5.355029 \mathrm{E}+02$ & 474.512 & 283.1089 & 9.3852 & 4.287822 & 1.000718 \\
\hline $\begin{array}{l}\text { 5.MLP } \\
\text { 6-11-1 }\end{array}$ & $1.455004 \mathrm{E}+02$ & 172.496 & 48.1594 & 7.0768 & 1.869014 & 0.999965 \\
\hline Average & $9.619103 \mathrm{E}+11$ & 811.170 & 117.5186 & 38.7279 & 2.434200 & 1.001971 \\
\hline
\end{tabular}

The table shows that based on the prediction models (retained artificial neural networks) the share of the price of oil in the value of the euro relative to the value of USD is almost imperceptible (2. MLP 6-11-1) or up to 1.88\% (5. MLP 6-11-1). It is therefore possible to answer the research questions:

- Question 1: Yes, the EUR/USD exchange rate is to a certain extent dependent on the price of Brent Crude. The dependence is evident and without doubt, a result which can be seen in particular based on the results of Set 1 of the input variables. The value of the correlation coefficient was almost 0.7 or above.

- Question 2: Yes, it is possible to measure the influence of the price of Brent Crude on the EUR/USD exchange rate. The influence is up to $1.88 \%$ depending on the prediction model used, all of which have approximately the same parameters. Given the aggregate EUR/USD exchange rate variable, this influence can be viewed as relatively substantial.

The results show that we can relatively accurately predict the impact of changes in the price of Brent Crude based on the EUR/USD exchange rate. This not only enables us to better predict the impact of such changes on international trade, but, with reference to Nonejad (2020), also the impact of the price of Brent Crude on the performance of national economies.

The price of oil therefore directly affects the economy of the European Union, a finding also presented by Benada (2014) and Vrontsi et al. (2015). Horák et al. (2020) claim that the price of oil has a significant impact on the development of the world and national economies, with the share in GDP shown as significant. The influence of the price of oil on exchange rates was examined by Baek \& Kim (2019), Novotný (2012) and Breitenfeller \& Cuaresma (2008), who all presented strong evidence in agreement of this significant impact. To draw such a conclusion, a number of models have been used based on statistical methods to predict oil prices. Chai et al. (2019), for example, used a hybrid model based on the fuzzy approach. Nevertheless, only a few authors, e.g. Ramyar \& Kianfar (2019) and Tairan et al. (2019), employed advanced innovative approaches us- 
ing artificial neural networks. Ramyar \& Kianfar (2019) also suggested an MLP neural network for prediction purposes. However, they focused on the suitability of the model against that of a created vector autoregressive model. While the authors of this article also used RBF networks for prediction purposes, our calculation was performed in the form of a time delay experiment. Tairan et al. (2019) used artificial neural networks together with other methods in a hybrid metaheuristic method for oil price prediction. However, they did not deal with exchange rates. Due to the use of artificial intelligence, the involvement of exchange rates, along with the use of an experiment using delayed time series, this contribution can therefore be considered innovative.

\section{CONCLUSION}

Oil as a key commodity and a pillar of the world economy which continues to play a role in the daily lives of all of us. Oil is a source of energy; it is a force that makes means of transport move; it is a raw material for the production of plastics. Oil reserves have made some formerly poor countries rich and fast-developing. However, the question remains as to how oil influences those countries that extract limited amounts of oil or none at all and are therefore dependent on imports. It is clear that its influence as a commodity, for energy and as a raw material is direct. In the past, it could also be assumed that there was an indirect or secondary influence.

Our study not only sought to confirm the secondary effect, but also quantify it in the form of the impact on the value of the Euro relative to the value of USD, a currency that is used in global markets and is used by many countries as a reserve currency. Recent figures indicate that the Euro accounts for $27 \%$ of all world foreign exchange reserves. It ranks second behind the USD in terms of importance of national currencies. The results of our contribution show that the effect of the price of Brent Crude on the value of the Euro relative to the value of USD is almost $1.88 \%$, making the impact of Brent Crude on the Euro relative to the value of USD very significant. It is clear that this relatively significant influence can slow down or, on the contrary, accelerate the activity in national economies. Within this context, it is possible to predict the impact on future GDP growth of the country on the basis of a time series model in which the influence of the price of Brent Crude on the development of the EUR/USD exchange rate is reflected. The results of our research can be applied to predicting the GDP of the countries trading with Eurozone countries. It could also be used by financial market traders to estimate the development of individually traded currencies. Based on the development of the price of Brent Crude, the development of the EUR/USD exchange rate and that of other currencies could be estimated more accurately.

The aim of this article was to determine the influence of the development of the international price of oil on the value of the Euro relative to the value of USD. Models built to predict this often show a great deal of simplification. However, this is not the case when variables such as the EUR/USD exchange rate and the price of Brent Crude are incorporated. Our study verified that:

- The EUR/USD exchange rate is also dependent on the price of Brent Crude.

- MLP networks generate more accurate predictions.

- It is necessary to capture developments across time series. 
Our results show that we can relatively accurately predict the impact of changes in the price of Brent Crude on the EUR/USD exchange rate. This not only enables us to better predict the impact of such changes on international trade, but also the impact of the price of Brent Crude on the performance of national economies. This method can greatly refine the estimates of analysts of banks and financial institutions. The aim of this article has therefore been met.

In our study a clear relationship between the price of Brent Crude and the EUR/USD exchange rate was established and quantified. Economic analysts, managers and investors can therefore use the results to more accurately predict developments in the EUR/USD exchange rate. This means they will also be able to better predict what will happen in the economies of Eurozone countries and in Europe in general, in countries economically connected to the Eurozone, as well as in individual companies working with the Euro. Managers and entrepreneurs will also be able to create more accurate plans. Neural networks can often find interdependence even where there is a strong non-linearity. Nuances are revealed that classical statistical methods cannot detect. In our case, the neural networks not only found a dependence that may seem obvious, but were also able to quantify the specific effect of the price of Brent Crude on the EUR/USD exchange rate, which would be difficult for classical statistical methods to detect.

Certain limitations of this study can also be idenfitied. The results are only valid if the mechanisms that determine the price of Brent Crude and the EUR/USD exchange rate are driven by the market forces of supply and demand. Should this change in any way, the relationship would need to be re-verified. It should also be noted that the conclusion has been drawn on the basis of an analysis of two time series over a period of five years in which there were no extreme fluctuations, for example, limited oil extraction due to a war, which begs the question of how such an extreme situation would affect the relationship of the time series examined. Although the likelihood of an extreme situation occurring is minimal, it does represent a real risk, as oil is also extracted by the countries located in politically unstable areas.

Our further research will focus on two directions. Firstly, an examination of the two timeseries in a shorter period than one day seems to be promising. Data exchanges in the present world as well as developments in the price of Brent Crude and the EUR/USD exchange rate are rapid and subject to change even by the minute. Secondly, further research will focus on the impact of the development of the price of Brent Crude on the performance of national economies and that of the EU respectively.

\section{References}

1. Aamir, M., Shabri, A., \& Ishaq, M. (2018). Improving forecasting accuracy of crude oil prices using decomposition ensemble model with reconstruction of IMFs based on ARIMA model. Malaysian Journal of Fundamental and Applied Sciences, 14 (4), 471-483. https://doi.org/10.11113/ mjfas.v14n4.1013

2. Baek, J., \& Kim, H. Y. (2019). On the relation between crude oil prices and exchange rates in sub-saharan African countries. A nonlinear ARDL approach. Journal of International Trade \& Economic Development, 29 (1), 119-130. https://doi.org/10.1080/09638199.2019.1638436 
3. Baghstani, H., Chazi, A., \& Khallaf, A. (2019). A directional analysis of oil prices and real exchange rates in BRIC countries. Research in International Business and Finance, 50, 450-456. https://doi.org/ 10.1016/j.ribaf.2019.06.013

4. Benada, L. (2014). Effect of Crude Oil on the Prague Stock Exchange. Procedia-Social and Behavioral Sciences, 109, 1316-1321. https://doi.org/10.1016/j.sbspro.2013.12.631

5. Breitenfeller, A., \& Cuaresma J. C. (2009). Crude oil prices and the USD/EUR exchange rate. Monetary Policy \& the Economy, (4), 102-121.

6. Chai, J., Y., Wang, S., Wang, \& Wang, Y. (2019). A decomposition-integration model with dynamic fuzzy reconstruction for crude oil price prediction and the implications for sustainable development. Journal of Cleaner Production, 229, 775-786. https://doi.org/10.1016/j. jclepro.2019.04.393

7. Ferreira P., Pereira, E. J. A. L., \& Pereira, H. B. B. (2020). The exposure of European Union productive sectors to oil price changes. Sustainability, 14 (4). https://doi.org/ 10.3390/ su12041620

8. Goel, R. K., \& Gupta, R. (2019). Impact of crude oil on exchange rate and stock market indices of BRICS nations. JIMS8M-The Journal of Indian Management \& Strategy, 24 (3), 25-34. https://doi.org/ 10.5958/0973-9343.2019.00021.8

9. Horák, J., Vrbka, J., \& Krulický, T. (2020). Using RBF neural networks to identify relationship between development of oil prices in world market and value of Chinese currency. SHS Web of Conferences: Innovative Economic Symposium 2019: Potential of the Eurasian Economic Union, 73. České Budějovice, Czech Republic. https://doi.org/10.1051/shsconf/20207301008

10. Horák. J. (2019). Using artificial intelligence to analyse businesses in agriculture. SHS Web of Conferences - Innovative Economic Symposium 2018: Milestones and Trends of World Economy, 61. České Budějovice, Czech Republic. https://doi.org/10.1051/ shsconf/20196101005

11. Investing.com (2019a). Currencies: EUR-USD. Retrieved November 22, 2019, from https:// www.investing.com/currencies/eur-usd

12. Investing.com (2019b). Commodities: Brent oil historical data. Retrieved November 22, 2019, from https://www.investing.com/commodities/brent-oil-historical-data

13. Ji, Q., Shazad, S. J. H., Bouri, E., \& Sulema, M. T. (2020). Dynamic structural impacts of oil shocks on exchange rates: lessons to learn. Journal of Economic Structures, 9 (1). https://doi. org/10.1186/s40008-020-00194-5

14. Kaffash, S., Aktas, E., \& Tajik, M. (2020). The impact of oil price changes on efficiency of banks: An application in the Middle East oil exporting countries using SORM-DEA. RairoOperations Research, 54 (3), 719-748. https://doi.org/ 10.1051/ro/2019009

15. Liu, S., Fang, W., Gao, X., An, F., Jiang \& Li, Y. (2019). Long-term memory dynamics of crude oil price spread in non-dollar countries under the influence of exchange rates. Energy, 182, 753-764. https://doi.org/10.1016/j.energy.2019.06.072

16. Mirdala, R., \& Ďurčová, J. (2016). Exchange Rate Pass-Through to Domestic Prices in New EU Member Countries. Politická Ekonomie, 64 (4), 377-404. https://doi.org/10.18267/j. polek.1077 
17. Nonejad, N. (2020). Crude oil price volatility and short-term predictability of the real U.S. GDP growth rate. Economic Letters, 186. https://doi.org/10.1016/j.econlet.2019.108527

18. Novotný, F. (2012). The Link Between the Brent Crude Oil Price and the US Dollar Exchange Rate. Prague Economic Papers, 21 (2), 220-232. https://doi.org/10.18267/j.pep.420

19. Oberholzer, B. (2017). Monetary policy and crude oil: Prices, production and consumption. Cheltenham: Edward Elgar Publishing Limited.

20. Qiang, W., Lin, A., Zhao, C., Liu, Z., Liu, M., \& Wang, X. (2019). The impact of international crude oil price fluctuation on the exchange rate of petroleum-importing countries: a summary of recent studies. Natural Hazards, 2019, 95 (1-2), 227-239. https://doi.org/10.1007/s11069018-3501-y

21. Ramyar, S., \& Kianfar, F. (2019). Forecasting Crude Oil Prices: A Comparison Between Artificial Neural Networks and Vector Autoregressive Models. Computational Economics, 53 (2), 743-761. https://doi.org/10.1007/s10614-017-9764-7

22. Tairan, N., Shah, H., \& Aleryani, A. (2019). Prediction of Crude Oil Prices using Hybrid Guided Best-So-Far Honey Bees Algorithm-Neural Networks. International Journal of Advanced Computer Science and Applications, 10 (5), 317-330.

23. Vrontisi, Z., Kitous, A. G., Saveyn, B., \& Vandyck T. (2015). Impact of low oil prices on the EU economy. Scientific and Technical Research Reports, Publications Office of the European Union.

24. Zizkov, D., Njegic, J., \& Balaban, S. (2019). Revealing the nexus between oil and exchange rate in the major emerging markets - The timescale analysis. International Journal of Finance \& Economics, 24 (2), 685-697. https://doi.org/10.1002/ijfe.1686

\section{Contact information}

prof. Ing. Marek. Vochozkea, $M B A, P b D$.

Institute of Technology and Business in Ceské

Budèjovice, Okrǔ̌ni 517/10, 37001 Ceské

Budéjovice

School of Expertness and Valuation

Crech Republic

E-mail:vochozka@mail.vstecb.cr.

ORCID: 0000-0002-1938-6957

Ing. Zurana Rowland, $M B A, P b D$.

Institute of Technology and Business in Ceské

Budéjovice, Okeruð̌ni 517/10, 37001 České

Budéjovice

School of Expertness and Valuation

Czech Republic

E-mail:rowland@mail.vstecb.cz.

ORCID: 0000-0002-7792-8873
Mgr. Petr Suler, PhD.

Institute of Technology and Business in Ceské

Budějovice, Okruð̌ni 517/10, 37001 Ceské Budějovice

School of Expertness and Valuation

Czech Republic

E-mail:petr.suler@cez:cr.

ORCID:0000-0001-7562-0659

doc. Ing. Josef Marousek, Ph.D.

Institute of Technology and Business in Ceské

Budějovice, Okeružni 517/10, 37001 České Budějovice

Faculty of Technology

Czech Republic

E-mail:marousek@mail.vstecb.cr.

ORCID: 0000-0001-5175-1961 


\section{Appendix 1}

Set 1: Retained neural networks with a 5-day time delay. Source: own research

\begin{tabular}{|c|c|c|c|c|c|c|c|c|c|c|c|}
\hline Index & Network & $\begin{array}{c}\text { Training } \\
\text { perf. }\end{array}$ & Test perf. & $\begin{array}{c}\text { Validation } \\
\text { perf. }\end{array}$ & $\begin{array}{c}\text { Training } \\
\text { error }\end{array}$ & Test error & $\begin{array}{c}\text { Validation } \\
\text { error }\end{array}$ & $\begin{array}{c}\text { Training } \\
\text { algorithm }\end{array}$ & $\begin{array}{c}\text { Error } \\
\text { function }\end{array}$ & $\begin{array}{c}\text { Hidden } \\
\text { activation }\end{array}$ & $\begin{array}{c}\text { Output } \\
\text { activation }\end{array}$ \\
\hline 1 & RBF 1-22-1 & 0.697366 & 0.675152 & 0.720606 & 0.000712 & 0.000709 & 0.000698 & RBFT & SOS & Gaussian & Identity \\
\hline 2 & RBF 1-30-1 & 0.706526 & 0.643863 & 0.718132 & 0.000695 & 0.000772 & 0.000707 & RBFT & SOS & Gaussian & Identity \\
\hline 3 & RBF 1-25-1 & 0.703240 & 0.661576 & 0.724401 & 0.000701 & 0.000737 & 0.000694 & RBFT & SOS & Gaussian & Identity \\
\hline 4 & RBF 1-28-1 & 0.706741 & 0.658395 & 0.715921 & 0.000694 & 0.000747 & 0.000712 & RBFT & SOS & Gaussian & Identity \\
\hline 5 & RBF 1-23-1 & 0.697363 & 0.664091 & 0.716033 & 0.000712 & 0.000734 & 0.000706 & RBFT & SOS & Gaussian & Identity \\
\hline
\end{tabular}

\section{Appendix 2}

Set 1: Retained neural networks with a 10-day time delay. Source: own research

\begin{tabular}{|c|c|c|c|c|c|c|c|c|c|c|c|}
\hline Index & Network & $\begin{array}{c}\text { Training } \\
\text { perf. }\end{array}$ & Test perf. & $\begin{array}{c}\text { Validation } \\
\text { perf. }\end{array}$ & $\begin{array}{c}\text { Training } \\
\text { error }\end{array}$ & Test error & $\begin{array}{c}\text { Validation } \\
\text { error }\end{array}$ & $\begin{array}{c}\text { Training } \\
\text { algorithm }\end{array}$ & $\begin{array}{c}\text { Error } \\
\text { function }\end{array}$ & $\begin{array}{c}\text { Hidden } \\
\text { activation }\end{array}$ & $\begin{array}{c}\text { Output } \\
\text { activation }\end{array}$ \\
\hline 1 & RBF 1-26-1 & 0.707501 & 0.660561 & 0.640189 & 0.000676 & 0.000751 & 0.000785 & RBFT & SOS & Gaussian & Identity \\
\hline 2 & RBF 1-29-1 & 0.721542 & 0.625561 & 0.642704 & 0.000649 & 0.000814 & 0.000788 & RBFT & SOS & Gaussian & Identity \\
\hline 3 & RBF 1-30-1 & 0.705162 & 0.678818 & 0.640267 & 0.000681 & 0.000720 & 0.000788 & RBFT & SOS & Gaussian & Identity \\
\hline 4 & RBF 1-30-1 & 0.704139 & 0.650749 & 0.643182 & 0.000684 & 0.000767 & 0.000774 & RBFT & SOS & Gaussian & Identity \\
\hline 5 & RBF 1-23-1 & 0.697571 & 0.679908 & 0.645041 & 0.000698 & 0.000715 & 0.000776 & RBFT & SOS & Gaussian & Identity \\
\hline
\end{tabular}

\section{Appendix 3}

Set 1: Retained neural networks with a 30-day time delay. Source: own research

\begin{tabular}{|c|c|c|c|c|c|c|c|c|c|c|c|}
\hline Index & Network & $\begin{array}{c}\text { Training } \\
\text { perf. }\end{array}$ & Test perf. & $\begin{array}{c}\text { Validation } \\
\text { perf. }\end{array}$ & $\begin{array}{c}\text { Training } \\
\text { error }\end{array}$ & Test error & $\begin{array}{c}\text { Validation } \\
\text { error }\end{array}$ & $\begin{array}{c}\text { Training } \\
\text { algorithm }\end{array}$ & $\begin{array}{c}\text { Error } \\
\text { function }\end{array}$ & $\begin{array}{c}\text { Hidden } \\
\text { activation }\end{array}$ & $\begin{array}{c}\text { Output } \\
\text { activation }\end{array}$ \\
\hline 1 & MLP 1-7-1 & 0.624135 & 0.619785 & 0.598075 & 0.000740 & 0.000711 & 0.000865 & BFGS 154 & SOS & Tanh & Logistic \\
\hline 2 & MLP 1-7-1 & 0.626805 & 0.617079 & 0.599862 & 0.000735 & 0.000714 & 0.000855 & BFGS 9999 & SOS & Tanh & Logistic \\
\hline 3 & MLP 1-6-1 & 0.626750 & 0.617917 & 0.599623 & 0.000735 & 0.000713 & 0.000856 & BFGS 321 & SOS & Tanh & Logistic \\
\hline 4 & MLP 1-5-1 & 0.622051 & 0.619130 & 0.598869 & 0.000745 & 0.000721 & 0.000864 & BFGS 188 & SOS & Logistic & Logistic \\
\hline 5 & MLP 1-8-1 & 0.626540 & 0.619749 & 0.599748 & 0.000735 & 0.000710 & 0.000855 & BFGS 270 & SOS & Tanh & Logistic \\
\hline
\end{tabular}

\section{Appendix 4}

Set 2: Retained neural networks with a 5-day time delay. Source: own research

\begin{tabular}{|c|l|c|c|c|c|c|c|c|c|c|c|}
\hline Index & Network & $\begin{array}{c}\text { Training } \\
\text { perf. }\end{array}$ & Test perf. & $\begin{array}{c}\text { Validation } \\
\text { perf. }\end{array}$ & $\begin{array}{c}\text { Training } \\
\text { error }\end{array}$ & Test error & $\begin{array}{c}\text { Validation } \\
\text { error }\end{array}$ & $\begin{array}{c}\text { Training } \\
\text { algorithm }\end{array}$ & $\begin{array}{c}\text { Error } \\
\text { function }\end{array}$ & $\begin{array}{c}\text { Hidden } \\
\text { activation }\end{array}$ & $\begin{array}{c}\text { Output } \\
\text { activation }\end{array}$ \\
\hline 1 & MLP 6-11-1 & 0.982779 & 0.977575 & 0.982413 & 0.000047 & 0.000057 & 0.000051 & BFGS 377 & SOS & Logistic & Tanh \\
\hline 2 & MLP 6-10-1 & 0.983218 & 0.979218 & 0.981626 & 0.000046 & 0.000053 & 0.000053 & BFGS 425 & SOS & Tanh & Sine \\
\hline 3 & MLP 6-9-1 & 0.980376 & 0.977044 & 0.981499 & 0.000054 & 0.000058 & 0.000053 & BFGS 402 & SOS & Tanh & Identity \\
\hline 4 & MLP 6-11-1 & 0.979934 & 0.975837 & 0.981782 & 0.000055 & 0.000061 & 0.000052 & BFGS 389 & SOS & Tanh & Tanh \\
\hline 5 & MLP 6-10-1 & 0.982107 & 0.976030 & 0.981315 & 0.000049 & 0.000062 & 0.000054 & BFGS 251 & SOS & Tanh & Identity \\
\hline
\end{tabular}

\section{Appendix 5}

Set 2: Retained neural networks with a 10-day delay. Source: own research

\begin{tabular}{|c|l|c|c|c|c|c|c|c|c|c|c|}
\hline Index & Network & $\begin{array}{c}\text { Training } \\
\text { perf. }\end{array}$ & Test perf. & $\begin{array}{c}\text { Validation } \\
\text { perf. }\end{array}$ & $\begin{array}{c}\text { Training } \\
\text { error }\end{array}$ & Test error & $\begin{array}{c}\text { Validation } \\
\text { error }\end{array}$ & $\begin{array}{c}\text { Training } \\
\text { algorithm }\end{array}$ & $\begin{array}{c}\text { Error } \\
\text { function }\end{array}$ & $\begin{array}{c}\text { Hidden } \\
\text { activation }\end{array}$ & $\begin{array}{c}\text { Output } \\
\text { activation }\end{array}$ \\
\hline 1 & MLP 6-8-1 & 0.978408 & 0.977063 & 0.974600 & 0.000058 & 0.000061 & 0.000067 & BFGS 338 & SOS & Tanh & Logistic \\
\hline 2 & MLP 6-11-1 & 0.981226 & 0.975911 & 0.976234 & 0.000050 & 0.000063 & 0.000062 & BFGS 419 & SOS & Tanh & Sine \\
\hline 3 & MLP 6-9-1 & 0.980176 & 0.978657 & 0.974759 & 0.000053 & 0.000056 & 0.000067 & BFGS 468 & SOS & Tanh & Identity \\
\hline 4 & MLP 6-11-1 & 0.982226 & 0.979472 & 0.974485 & 0.000048 & 0.000054 & 0.000066 & BFGS 320 & SOS & Tanh & Sine \\
\hline 5 & MLP 6-9-1 & 0.980558 & 0.980122 & 0.975993 & 0.000052 & 0.000053 & 0.000063 & BFGS 315 & SOS & Logistic & Tanh \\
\hline
\end{tabular}




\section{Appendix 6}

Set 2: Retained neural networks with a 30-day delay. Source: own research

\begin{tabular}{|c|l|c|c|c|c|c|c|c|c|c|c|}
\hline Index & Network & $\begin{array}{c}\text { Training } \\
\text { perf. }\end{array}$ & Test perf. & $\begin{array}{c}\text { Validation } \\
\text { perf. }\end{array}$ & $\begin{array}{c}\text { Training } \\
\text { error }\end{array}$ & Test error & $\begin{array}{c}\text { Validation } \\
\text { error }\end{array}$ & $\begin{array}{c}\text { Training } \\
\text { algorithm }\end{array}$ & $\begin{array}{c}\text { Error } \\
\text { function }\end{array}$ & $\begin{array}{c}\text { Hidden } \\
\text { activation }\end{array}$ & $\begin{array}{c}\text { Output } \\
\text { activation }\end{array}$ \\
\hline 1 & MLP 6-11-1 & 0.980192 & 0.975591 & 0.980126 & 0.000047 & 0.000055 & 0.000053 & BFGS 393 & SOS & Tanh & Tanh \\
\hline 2 & MLP 6-11-1 & 0.981424 & 0.974255 & 0.980434 & 0.000045 & 0.000058 & 0.000052 & BFGS 394 & SOS & Tanh & Sine \\
\hline 3 & MLP 6-11-1 & 0.979505 & 0.974208 & 0.982267 & 0.000049 & 0.000058 & 0.000047 & BFGS 605 & SOS & Logistic & Exponential \\
\hline 4 & MLP 6-11-1 & 0.980005 & 0.973384 & 0.980498 & 0.000048 & 0.000060 & 0.000052 & BFGS 358 & SOS & Logistic & Tanh \\
\hline 5 & MLP 6-11-1 & 0.978925 & 0.974867 & 0.979740 & 0.000050 & 0.000057 & 0.000053 & BFGS 358 & SOS & Tanh & Identity \\
\hline
\end{tabular}

